\title{
From Selma, Alabama, to Derry, Northern Ireland: Media Images and their Influence on Civil Rights Demonstrations
}

Bonnye Stuart

Mass Communication \& Journalism, Winthrop University, USA

*Corresponding author: Bonnye Stuart, Mass Communication \& Journalism, Winthrop University, USA, Tel: +1-803-323-221; E-mail: stuartb@winthrop.edu

Rec date: May 09, 2014; Acc date: June 20, 2014; Pub date: June 27, 2014

Copyright: () 2014 Stuart B. This is an open-access article distributed under the terms of the Creative Commons Attribution License, which permits unrestricted use, distribution, and reproduction in any medium, provided the original author and source are credited.

\begin{abstract}
Using Ball-Rokeach and DeFleur's Media System Dependency (MSD) theory that during times of conflict the public looks to the media to answer questions ease uncertainty and effect outcomes, this paper will analyze televised images of the U.S. Civil Rights movement and their impact on demonstrations during the Northern Ireland conflict.

Matthew Loveless, discussing media effects, said, "The theory of media dependency states that for societies in states of crisis or instability, citizens are more reliant on mass media for information and as such are more susceptible to their effects." Douglas Blanks Hindman studying media system dependency before and after the 9/11 attacks on the U.S., cites Ball-Rokeach \& DeFleur, saying, "The media system dependency model suggests that under conditions of ambiguity, as in the case of social system disruptions resulting from natural or human-made disasters, the mass media will become the public's primary information source, and media effects will become more pronounced."

This paper will examine information dissemination (televised images of U.S. Civil Rights marches) as a source of power influencing public perception in Northern Ireland and showing street marches an effective form of demonstration, and will specifically focus on televised news coverage of the 1965 Selma to Montgomery marches and their influence on demonstrations in Northern Ireland, 1968-69. Marching as a demonstration technique, mediasavvy leaders and the singing of "We Shall Overcome" will be explored through documented news coverage and anecdotal research.
\end{abstract}

Keywords: Civil rights; Television effects; Media history; Televised demonstrations

\section{Introduction}

Television news broadcasts allow audiences in one part of the world to be aware of and participate in happenings around the globe. In certain instances, they can also serve as models of possible actions, stimulating viewers in one area to recreate events occurring in another part of the world in the hopes of achieving similar results.

In the U.S. in the 1960s, television news set a national agenda and awakened its mass audience to the civil rights agenda. The power and reach of global media subsequently enabled broadcast images of the U.S. movement for equality to play an important role in the civil rights movement of Northern Ireland. This paper will use Ball-Rokeach's media dependency theory to illustrate the power of media images as providers of immediate information, referential examples, and rallying icons and their influence on consensus building. Research will illustrate the connection between mediated U.S. civil rights images, often graphic and sensational, as seen on national and international news programs and the events of the civil rights movement in Northern Ireland. Of course, it is acknowledged that much information came to the people of Northern Ireland via newspapers and radio, but powerful moving images, broadcast into homes of viewers, made the struggle across the Atlantic personal and real and put human faces and bodies to the struggling voices offering new and workable strategies.

Specifically this research will attempt to show that the media images of the Selma to Montgomery marches of 1965, broadcast into Northern Ireland, added to the leadership's understanding of dissent practices and contributed to the average citizen's hope that achieving civil rights through public demonstration was possible. It will also illustrate the replication of movement tactics, slogans and songs and the referential use of the image of Martin Luther King as a symbol of the cause. A Derry to Belfast march, January 1-4, was planned after the bloody demonstration in Derry in October of 1968. This march was specifically modeled on the Selma to Montgomery marches and significantly impacted the Northern Ireland movement [1].

This paper will make few ideological or political comparisons of the U.S. and Northern Ireland civil rights movements. Historians and activists have been fairly vocal that the two movements were not the same on many levels. This paper will attempt to show, however, that television images broadcast into Northern Ireland had a profound impact on the leaders and people of Northern Ireland in their struggle for civil rights. A case will be made that television viewers in Northern Ireland found direction in the persona of Martin Luther King, a strength in the movement's spiritual song, We Shall Overcome" and a solidarity of belief that they could achieve political objectives by means of public marches and demonstrations. Finally, it will be suggested that the people of Northern Ireland came to depend on the television 
media for information and visible examples of protest tactics and results [2].

\section{Theories of Media Impact}

The media system dependency theory of early proponents Sandra Ball-Rokeach and Melvin DeFleur states that citizens depend on media to fulfill informational needs, and this dependency gives the media increased power and influence over viewers [3]. Essential to this theory are several integral relationships between the medium and its audience in the contexts of time, culture, and situation. The theory acknowledges that people depend on the media for a variety of reasons and not all people depend on the media equally. Underlying factors, such as accessibility, credibility, and the fulfillment of needs, often affect the extent of media dependence.

A second criteria influencing media dependency, one crucial to this study, is that of social stability. In times of insecurity and stress, when social systems or beliefs are in conflict [4], people look toward the media as a primary provider of information. According to BallRokeach, media power is derived "from control over information resources that others - individuals, groups, organizations, social systems, societies - must access to attain their goals" $(1998,16)$.

Media become more powerful and essential when people are faced with a crisis or uncertainty. Matthew Loveless [5] explains: "The theory of media dependency states that for societies in states of crisis or instability, citizens are more reliant on mass media for information and as such are more susceptible to their effects"(162).

Historically, broadcast images as agents of change have faced heavy criticism stemming from objections to their practice of appealing to the lowest common denominator of audiences, their presentation of a limited spectrum of opinion, and their propensity to put commercialism before public interest. Other critics see media's power to impact large groups of citizens as a negative influence rooted in western ideology and a narrow agenda-setting perspective [6].

Paul Klein, NBC executive, audience researcher and developer of the Least Objectionable Program (LOP) theory said "network television maximizes its audience by offering non-controversial programs [6]. Television critics often label broadcasting as a commercial medium which entertains or informs its viewers only secondarily to selling goods and western ideologies; others claim it is a manipulator of political images and ideological messages. Daniel Bell states that "television and the mass media are instrumental in promoting a new consumer ethic and hedonistic lifestyle that contradicts the older capitalistic-protestant production ethic with its emphasis on hard work, saving, delayed gratification, the family, religion, and other traditional values" [6]. "Neoconservatives such as Aaron Wildavsky, Daniel Moynihan, Robert Nisbet, and Samuel Huntington," says media culture theorist, Douglas Kellner, "all argue that television has eroded respect for authority by exposing political scandals, business corruption and failures, while fostering cynicism, distrust, and disrespect for the system" (44).

Despite the negative criticism of television, historical evidence shows that easily accessible information delivered to the people can act as a societal change agent and influence mass audiences. As satellite transmissions penetrate further into previously disconnected regions lacking in information resources and as viewing images from around the world becomes the daily norm, it is important to study the power of television.
In support of media dependency theory, Kellner states that U.S. television is a powerful information source "...assuming increasingly important and complex social functions in contemporary societies... contributing to the ritualization of politics; reinforcing spectator politics, it is itself an autonomous political power ....for many other countries in the world" (31).

Ball-Rokeach's media dependency theory describes the relationship between media and society. Tying into the uses and gratification theory (that people use the media for their own needs) the media dependency theory states that the more a person depends on the media to satisfy these needs, the more important the media will become to that individual or group of individuals. Ball-Rokeach argues that people are dependent on media outlets for information and this dependency increases and decreases as the need for more information, from within and without their geographic area and from multiple perspectives, becomes necessary to attain goals and objectives (1998).

History of two events: Selma to Montgomery March (1965) and the Derry to Belfast March (1968)

\section{The U.S.}

By 1965, the Civil Rights Movement in the United States was well under way, yet no real progress had been made. Segregation was still rampant though the Brown v. Board of Education landmark decision to desegregate U.S. schools was more than 10 years old, the 250,000 strong march on Washington had garnered national attention and Rev. Martin Luther King, Jr. had won the 1964 Nobel Peace Prize. Despite the passage of the Civil Rights Act of 1964, President Johnson, though sympathetic to the cause, had not yet demanded the nation to end its deeply-rooted and pervasive segregation.

Activists took on the challenge of ensuring voter's rights protection under the law and announced an organized march through the streets of Selma, Alabama, for Sunday, March 7, 1965. About 525 black citizens left Brown Chapel AME Church and headed across the Edmund Pettus Bridge spanning the Alabama River. More than 50 Alabama State troopers lay in wait just 300 yards beyond the end of the bridge to enforce the ban imposed by the Governor of Alabama. When the marchers were ordered to stop and turn around, they kneeled to pray. John Lewis, one of the lead men in the march, later said, "All hell broke loose" [7]. Newsmen had been contained to a corner over 100 yards away, and though they reported losing sight of much of the action, they did report "fifteen or twenty nightsticks could be seen through the gas, flailing at the heads of the marchers" [8]. At the end of the altercation, more than 17 black citizens were hospitalized and another 40 were treated for minor injuries and tear gas effects. This confrontation quickly took on the moniker, Bloody Sunday, and subsequently vivid images of police brutality were seen on the nightly news [9].

The painful awakening of the American consciousness had begun. Senior editor for Look Magazine George Leonard wrote in a personal account of his civil rights activism: "There are moments ... when the senses of an entire nation become suddenly sharper, when pain pours in and the resulting outrage turns to action. One of these moments came, not on Sunday, March 7, when a group of Negroes at Selma were gassed, clubbed and trampled by horses, but on the following day when films of the event appeared on national television" [9]. 


\section{Leonard, watching the news from selma on television, reported}

The pictures were not particularly good. With the cameras rather far removed from the action and the skies partly overcast everything that happened took on the quality of an old newsreel. Yet this very quality, vague and half-silhouetted, gave the scene the vehemence and immediacy of a dream. The TV screen showed a column of Negroes striding along a highway. A force of Alabama troopers blocked their way. As the Negroes drew to a halt, a toneless voice drawled an order form a loudspeaker: In the interests of "public safety," the marchers were being told to turn back. A few moments passed, measured out in silence, as some of the troopers covered their faces with gas masks. There was a lurching movement on the left side of the screen; a heavy phalanx of troopers charged straight into the column, bowling the marchers over.

A shrill cry of terror, unlike any sound that had passed through a television set, rose up as the troopers lumbered forward, stumbling sometimes on the fallen bodies. The scene cut to charging horses, their hoofs flashing over the fallen. Another quick cut: a cloud of tear gas billowed over the highway. Periodically the top of a helmeted head emerged from the cloud, followed by a club on the upswing.

... my wife, sobbing, turned and walked away, saying, "I can't look any more."

... that night ... people, mostly unknown to one another, would move for a single purpose: to place themselves alongside the Negroes they had watched on television [10].

CBS showed footage of the altercation and NBC aired coverage as well, but $\mathrm{ABC}$ news would have the greatest impact on the country [11].

At 9:30 p.m., in an unprecedented move, $A B C$ interrupted its "Sunday Night Movie" and aired fifteen minutes of the violence in Selma. The film was Judgment at Nuremberg, a moving story of how German citizens had allowed Hitler's rise to power. Suddenly viewers were watching -- not Nazi Germany but Alabama. The poignant analogy made its mark on U.S. viewers [12].

The events in Selma made inaction unthinkable. "Religious, business, and political leaders expressed outrage, issued statements, and passed resolutions condemning Alabama law enforcement. By the second day, there were sit-ins in Los Angeles, traffic blockades in Chicago, and a 10,000-person march in Detroit. Sympathy protests, pickets, and demonstrations erupted in so many towns and cities that The New York Times was able to fill column after column of summaries from across the nation and Canada; more than a dozen young people gained entry to the White House, sat down, and refused to leave" [12].

That night, people who had previously been detached and isolated in their concerns, boarded planes, buses, trains, cars and traveled thousands of miles to support their fellow citizens. The media had acted as an agent for consensus and action.

Dr. King had been busy in Atlanta and had not joined the "Bloody Sunday" march. But now, committing himself anew to the Selma campaign, King joined the ranks of demonstrators and issued a call for another march from Selma to Montgomery on March 9, 1965. Just two days after the first confrontation on Pettus Bridge, more than 2000 supporters led by Martin Luther King, Jim Forman, James Farmer, Methodist Bishop John Wesley Lord and other clergymen linked arms and headed once again toward the infamous bridge. Stopped by a double line of state troopers, the crowd joined hands and began singing, "We Shall Overcome." Then after an exchange of words, the demonstrators turned around and walked back over the bridge to the church where they had started, agreeing not to challenge the prevailing court order prohibiting the march. During this "symbolic" march, tensions were high; many activists did not seek political sanction for their activities. But protestors were convinced by civil rights leaders to wait for "legal" permission to march to Montgomery [13].

On March 15, President Johnson gave a nationally televised speech for Voting Rights protection to Congress and 40 million television viewers. He vowed: "Their cause must be our cause, too!" and finished his speech with the words, "And We Shall Overcome." Johnson received a standing ovation for nearly a minute.

On March 21, the now-famous Selma to Montgomery march got underway. This time a federal court order forbade the state from blocking marchers who ultimately traveled a 54-mile route through rain and chilly temperatures. Televised images showed marchers singing songs of solidarity, including "We Shall Overcome." When they reached the Alabama capital four days later, a "Stars for Freedom" rally was held featuring Harry Belafonte, Frankie Laine, and Peter, Paul and Mary, among others. On the fifth and last day of the march, the number of protestors had grown to 25,000; King delivered his speech, "How Long, Not Long" next to the capitol building [14].

David Garrow [14], author of Protest at Selma, in an article, "How the Press Reported on Racism, and How It Didn't," said that the ensuing international uproar in the wake of global television coverage highlighted "the explosive potential of images" and their power to unite people not just in the U.S., but around the world (E14).

Television attracted a mass audience. "As veteran anchorman Walter Cronkite later explained, a demonstration now needed 'only enough people to fill the frame of a television camera to be a success'. Leaders at the forefront of the civil rights movement believed it had been absolutely crucial to exhibit "a dramatic clash between violent whites and nonviolent Negroes that would arouse the press, the pulpit, the politicians, and the president" [15]. The plan worked. People not only became aware of the adverse conditions of their fellow citizens, but began to support and work actively for the cause. As the movement grew, more and more people tuned into the nightly broadcasts to see the latest news on the now, full-fledged, Civil Rights Movement.

The Selma demonstrations brought legislative action. On March 17, 1965, President Johnson put pressure on both houses of Congress to pass the Voting Rights Act, which they did. He signed the bill into law on August 6, 1965.

\section{Northern Ireland}

In the early days of television broadcasting, Northern Ireland, as a part of the United Kingdom depended on the BBC (British Broadcasting Corporation) for its daily news. By the mid-1950's, however, the Independent Television Act ended that monopoly and ITV (Independent Television) companies began broadcasting more localized news in Northern Ireland. Citizens had access to wider range of perspectives than available on the traditional BBC. RTE, Raidió Teilifís Éireann, began operations in 1961, providing additional news outlets. These young broadcasting organizations brought news from a variety of sources from countries around the world. 
Ireland has a long history of civil unrest, but in the 1960s, a growing number of people in Northern Ireland, conservative and radical, began searching for effective ways to achieve the civil rights that had been denied them and others. Television became a major source of information for ordinary citizens as they began to identify and act on the options available to them in their demands for equality.

By 1962, the Irish Republican Army's (IRA) border campaign to unite Ireland was losing ground. Robert English in Armed Struggle: The History of the IRA, explains the situation, An IRA statement of 26 February announced the end of the border campaign ... acknowledging that foremost among the reasons for calling off the project had been 'the attitude of the general public whose minds have been deliberately distracted from the supreme issue facing the Irish people - the unity and freedom of Ireland' (75). The IRA's lack of organization contributed to its failures, but other factors were also at work, not the least of which was that "while they claimed to act for the Irish people, the Irish people seemed not to be interested in their doing so (76)."

But the climate of dispassion was changing. The people of Northern Ireland displayed a renewed rebellious spirit as they became more aware of citizens like themselves, in other countries, making progress in the demand for equal rights.

In May of 1963, three Dungannon housewives picketed against unfair housing. That the women were influenced by U.S. marches is reflected in the signs they carried with slogans: "Racial discrimination in Alabama Hits Dungannon" and "If Our Religion Is against Us Ship Us to Little Rock" [16]. Simon Prince in Northern Ireland's 68: Civil Rights, Global Revolt and the Origins of the Troubles, explains the increase in U.S. visibility in Northern Ireland, "In the weeks heading up to the protest, the American civil rights movement had once again become headline news around the world. Marches were held, sit-ins were staged, boycotts were imposed, and King got himself sent to jail..."(70).

Though the civil rights movement inspired activists throughout the 1960s, Prince says "the complexity of adopting ideas from across the Atlantic and adapting them to Northern Ireland conditions ensured that the process was slow and far from smooth. In the first stages, the African-American struggle influenced only the rhetoric. Comparing their condition to that of the black population from the Deep South was useful propaganda for the Dungannon housewives" (71). But in coming years U.S.-inspired activities, as witnessed on television, would be reflected more and more in Northern Ireland as the two campaigns progressed on separate continents. Prince notes that just three weeks after the Washington march that "the Dungannon Observer even advocated a Northern Ireland version of the March on Washington" (71).

New activist groups were forming. The Northern Ireland Civil Rights Association (NICRA) was founded in April of 1967 and joined with the Campaign for Social Justice (CSJ), started in 1964, and other groups, to hold civil rights demonstrations. English acknowledges the influence of the U.S. movement at this time, “... in the spring of 1968 the pace and tension of civil rights activity increased... the NICRA embarked on a series of protest marches, partly inspired by the American black civil rights example...(100).”

One of the first civil rights marches in Northern Ireland occurred in Derry on Saturday August 14, 1968, supported by more than 2,000 people singing "We shall Overcome." Activist Austin Currie had studied U.S. history at Queens University and knew the power of the media coverage. He felt ardently that Northern Ireland could benefit from the American example [17]. He supported Northern Ireland's first civil rights march, and was anxious to attract media documentation of the Irish struggle; he had seen U.S. media coverage of civil rights demonstrations on his own television and knew the benefits of powerful images. He suggested it was "time to get away from just disseminating facts and figures, time to get away from the civil liberties groups in Britain ... and to take it to the streets" [17]. Movement leaders were ultimately disappointed that the march received little media attention; they had seen powerful U.S. media images garner supporters from the rank and file and they wanted that for Northern Ireland.

Currie and other NICRA members had been distant but eager observers of the March on Washington. In a Trinity College speech, Currie said, "What interested those watching on their televisions in Northern Ireland was not why King embarked upon his last campaign but how he and his successors planned to gain mass support and the interest of the media" [17]. Activist Fred Heatley recalled that "the tactics of Martin Luther King in America had been absorbed inasmuch that it was felt by some that only public marches could draw wide attention to what we were trying to achieve" [17].

Martin Luther King, too, had been ignored by television news and politicians, as a consequence, the civil rights leader resorted to provoking the authorities. The resulting "savage scenes were what the American movement needed to attract media attention and thus secure federal intervention" [17]. Northern Ireland's civil rights coalition had taken inspiration from the black struggle for equality, but "key lessons from across the Atlantic still had to be learned" [17]. Currie put forth the idea that powerful television images of police attacking protestors were "needed to attract extensive media coverage, inspire previously passive people to take to the streets and force those in power to act" [17].

The next civil rights march would be held on October 5, 1968, in Derry, and Currie would be one of the leaders responsible for organizing it. Demonstrators convened at the Derry railway station in defiance of a ban by William Craig, Minister of Home Affairs; opposition forces gathered in force, as well. The march was reminiscent of Selma's Pettus Bridge march that ended in bloodshed and irrevocable ripple effects throughout the world. As the march began, clashes erupted between the Derry police who ambushed and attacked the 2000 demonstrators. The Royal Ulster Constabulary (RUC) wielded batons and shot water cannon at the unarmed crowd of marchers.

\section{Prince describes part of the scene}

"The water wagon directed a jet through an open window on the first floor of the house where the Ulster television camera crew was stationed. The BBC's team filming was also impaired. The Telefis Eireann cameraman, however, managed to record several hundred feet of film. A former BBC employee living in Derry contacted the current affairs department about this footage. Since the Irish Television Service's launch in 1961, the two national broadcasters had cooperated extensively. The BBC was therefore allowed to screen the dramatic Telefis Eireann film of the march on its regional and network news bulletins. The television coverage transformed the political situation... [and]... events in Northern Ireland were to remain on British television screens into the next century" (5). 
Bob Purdie [16], in Politics in the Streets: The origins of the civil rights movement in Northern Ireland, reports, "There was a brief attempt at a sit-down in front of the police lines, and a ragged snatch of 'We Shall Overcome' was sung" (141). At least 90 demonstrators were treated at local hospitals. Derry citizens had seen and been called to action by the Selma marches and now "it was Derry's turn to stage what had become familiar drama for the world's television viewers" [17].

\section{English further explains the situation}

The attack on the civil-rights marchers by the police on 5 October had been seen by television viewers all around the world. The government and police had tried to brazen it out, blaming the disturbance on the IRA and subversives. But there was no way they could refute the charges of brutality, or wish away the images of uniformed thugs batoning defenceless people (100).

Subsequently, the People's Democracy (PD) was organized at Queen's University in Belfast, in response to the bloodshed in Derry and this group reflected the radical student movements in the U.S. and Europe. Leaders Michael Farrell and Bernadette Devlin [18] personally acknowledge the U.S.-Northern Ireland connection and its influence on their civil disobedience tactics of sit-ins, marches, and picketing. English says, "Youthful radicals of the 1960s emerged as leaders and were influenced by 'the times-changing, optimistic radical mood' of the world"(92).

Making the case that televised images were influential on the leaders of the Northern Ireland movement is Bernadette Devlin (now DevlinMcAliskey) [19], a Queen's University student and founding member of the $\mathrm{PD}$, who became a prominent figure in the civil rights movement and was elected to Westminster in 1969 at the age of just 21. She answered the question, "Do you remember seeing any televised scenes of the U.S. Civil Rights movement?" with "Yes, I remember seeing people on television marching, sitting-down and sitting-in, and mass organizing. I was always talking about and referencing the events that I was witnessing on television." As to what she felt when she witnessed these images," she said, "I connected with them, we and the people in the U.S. seemed to be the same victims of prejudice and inequality. "So how much did the student leaders depend on the news and information coming from the U.S.? Devlin responded, "Everybody I knew was addicted to the news" [19].

Street violence was nothing new in Northern Ireland, but street politics were. This was a technique that citizens had seen on their television sets during the coverage of the U.S. Civil Rights movement. Activists came to realize that banning street demonstrations was "an effective government weapon against political protest, and that although letter writing to Stormont was a fine form of occupational therapy, it was unlikely to bring any worth while results" [20].

On November 16, 1968, a second civil rights march in Derry attracted 15,000-20,000 protestors to the Craigavon Bridge. Demonstrators halted peacefully at the police barriers. Much like Martin Luther King's "symbolic" march in Selma after the Pettus Bridge attack, no incidents occurred and the entire crowd staged a "sitdown." They decided to give O'Neill one last chance and declared a "truce" for one month without marches or demonstrations.

\section{Brian dooley describes the event}

The scene was reminiscent of the Selma protest in the US where, on March 7 1965, 400 people had set off to cross the Edmund Pettus Bridge and walk to Montgomery. The protestors were beaten back by the police with such ferocity that 7 March went down in American civil rights history as 'Bloody Sunday'... as in Selma, a huge number of Northern Ireland civil rights protestors returned to the scene of an earlier march broken up by police to restage the protest. When 15,000 civil rights marchers massed on Craigavon Bridge on 16 November a policeman who had been part of the cordon which stopped the original Derry march on 5 October was again on duty. 'It was an awesome sight, this mass of people coming across the Craigavon Bridge...' for a brief period we had gone marching mad ... people took to the streets singing 'We Shall Overcome' in Strabane, Armagh, Belfast, Dungannon and elsewhere (54).

With no evident progress being made, on January 1, 1969, imitating the Selma to Montgomery march, the PD, mostly students, began a 4day march from Belfast to Derry. Michael Farrell, Northern Ireland The Orange State, connects the two events: The march was modelled on the Selma-Montgomery march in Alabama in 1966, which had exposed the racist thuggery of America's deep South and forced the US government into major reforms. Demonstrators were repeatedly assulted along the way culminating in the Burntollet Bridge incident on January 4 where marchers were attacked by 200 antagonists with iron bars, bottles and stones while police watched on. Thirteen marchers required hospital treatment [18].

Devlin acknowledges the role that television images played in the events leading up to the Burntollet Bridge protest debacle, The long march to Derry on New Year's Day, 1969 was modeled on the Selma march and I remember watching a lot of coverage on Martin Luther King. I also remember singing U.S. spirituals such as 'We Shall Overcome,' 'We Shall Not Be Moved' and 'If you miss me at the back of the bus' [19]. Dooley, in Black and Green, connects the singing of spirituals by the people of Northern Ireland to the ritual of civil rights demonstrations when he describes a sit-in in July of 1968, where protestors, “... began to sing 'We Shall Overcome'... most had heard the song in snatches from the television ... and within months, tens of thousands of people who had never been on a protest of any kind would be marching across Northern Ireland, demanding civil rights and singing 'We Shall Overcome”(48).

References to the U.S. Civil Rights Movement, Matting Luther King, Jr., and the movement anthem, "We Shall Overcome" can be found throughout the chronicles of the time in Northern Ireland now known as "The Troubles." That most of the iconic images were seen by the Irish people via their television sets is evident and can be documented in the archives of ITN, RTE and BBCNI. Though not complete, the ITN and BBCNI resources provide ample evidence that numerous news programs were aired in Northern Ireland. Anecdotal evidence abounds from movement leaders, supporters, writers, historians, oral histories and written accounts, scholars and critics.

\section{U.S. Media Influence}

Ball-Rokeach's media dependency theory would suggest that in this uncertain time, the citizens of Northern Ireland looked toward media to provide them information not only about what was happening in their own country, but also about civil rights movements which had begun in the U.S., France and South Africa. Northern Ireland activists, civil rights leaders and common citizens identified a model for their 
cause half way around the world in the U.S. civil rights movement [21].

By the mid-60s, news stories of U.S. demonstrations were broadcast into Northern Ireland on a daily basis. The success of the demonstrations, both peaceful and riotous, the notice taken by politicians and those in power to effect change, and the ultimate implementation of legislation for equality was noted by a people hungry for their own civil rights. As viewers watched the newscasts they saw an effective model for their own fight against injustice. This time period also saw an increase in television sets in Northern Ireland. Danny Morrison, activist, said, "On my street of 25 houses, when we got our television set in 1958, we were the first and only, but by the mid-60s everyone had a TV set, though they were only black and white" [22]. Ordinary citizens now had access to extended television programming whether on their own sets or those of their neighbors.

April Carter, peace and reconciliation scholar, in Civil Resistance and Power Politics: The Experience of Non-violent Action from Gandhi to the Present, says, "The US civil rights movement inspired other non-violent struggles. It was one inspiration for the protests in Northern Ireland, 1967-72, against discrimination and Protestant domination of the political system..."(28).

Though Northern Ireland scholar Robert English cites inherent differences in the U.S. and Northern Ireland struggles, he says in Irish Freedom, the History of Nationalism in Ireland, that the fight for fair treatment of black citizens in the U.S. was echoed in the discrimination issues of Northern Ireland at the time [23]. And in "The Interplay of Non-violent and Violent Action in Northern Ireland, 1967-72," a chapter in Roberts and Ash's Civil Resistance and Power Politics, English says the scenes of violence exhibit "the use of technologies to very powerful effect. Television was among the civil rights marchers' best friends, raising international profile and blood pressure alike" (80).

English points out that the Northern Ireland civil rights movement was influenced by outside forces, and most of these were brought to the Irish people through the media. He quotes Gerry Adams, Irish Republican and Sinn Finn member,

People did not live their lives in isolation from the changes going on in the world outside. They identified to a greater or lesser extent with the music, the politics, the whole undefined movement of ideas and changes of style. Bob Dylan, the Beatles and the Rolling Stones, long hair and beads, the 'alternative society', music and fashion were all markers put down by a new generation against the complacencies of the previous one, and one of the most important messages to come across was that one could change the world" [24].

Richard English, when asked, "Did the people of Northern Ireland know about what was happening in the U.S. because they saw them on television?, answered, "Yes, for all the manifest differences between the two settings, there was a sense that what was happening in the U.S. influenced the direction and potential in Northern Ireland and TV was crucial"(Personal interview).

In "The Interplay of Non-violent and Violent Action in Northern Ireland, 1967-72," English again alludes to the influence of U.S. movement on the actions undertaken in Northern Ireland. He says, "The 1960s civil rights movement in Northern Ireland did involve a conscious glance toward civil rights in the U.S. [25]." Television facilitated this "look and learn" process.
Some have criticized the movement's use of "challenging the establishment" saying that "the wisdom of holding a provocative march with the intention of inflaming Ulster politics at this key moment in early 1969 must surely also be open to question." [26] But the leaders and the activists had seen positive results in similar U.S. actions. Media messages had assured them that their efforts would lead to success and equality. What they saw on their televisions in their homes and their neighbors' homes gave them the information they needed, the incentive to repeat what they had seen and the conviction that they, too, could win in the end.

Much credit for the January 1 march from Belfast to Derry has gone to the People's Democracy members who put new life into the civil rights campaign [26]. These leaders acknowledge the role U.S. media messages played in their resolve.

Danny Morrison, editor of Republican News 1975-79 and An Phoblacht/Republican News 1979-82, writer and leading Sinn Fein politician, says “...people of my age, my generation, we watched the civil rights movement in the States, we watched the Vietnam War and the anti-war protests" [26].

In a personal interview, Morrison adds: "I personally remember student sit-ins and anti-war demonstrations. Young people of my age associated with the civil rights movement and the anti-war demonstrations. Martin Luther King was seen as a huge figure who brought about change. He was extremely popular and was a powerful role model for our protests. It was the media that brought King and his ideas to our attention. You couldn't help but be political and be involved. The famous demonstration of October 5, filmed by the RTE cameraman, was based largely on the U.S. Selma to Montgomery marches."

Brian Dooley in Black and Green explores the connection between blacks in the U.S. and the Irish people. He says, "Civil rights activists in Northern Ireland borrowed slogans from black American protestors, called themselves 'white negroes' (ODochartaigh) [27] and identified in a positive way with the struggle across the Atlantic led by Martin Luther King"(1).

\section{Conclusion}

Modern media is a changing industry in which news is broadcast on a host of satellites to numerous network and cable channels. The hours of television news available to the average viewer has increased and availability continues to grow; twenty-four hour news services are not uncommon in many countries. Media scholars generally agree that broadcast news is neither neutral nor objective, but interpretative. It can be also argued that viewers, ultimately, give the news interpretation and meaning in relation to their circumstance.

Were media images the catalyst that spurred people in Northern Ireland to action? Brian Dooley gives strong evidence that it was.

\section{He reports,}

The early years of the 1960s saw ... a sharp increase in the number of television sets in Northern Ireland... most people in Northern Ireland would regard the broadcast media as the best source of news. British media coverage of the campaign for civil rights in the US in the first few years of the 1960s meant that Northern Irish viewers saw television reports of sit-ins at segregated eating facilities... thousands of people on protest marches and - most dramatically - the brutal treatment of non-violent protestors by some police forces. Gerry 
Adams credits media coverage of the black civil rights movement as contributing to an increased politicsation in Northern Ireland. 'Courtesy of television, we were able to see an example of the fact that you didn't just have to take it, you could fight back, he wrote' [28].

Michael Farrell, Queen's student and PD leader said young people “... were very influenced by seeing on television the American civil rights movement ... and I think there was a very general identification with it" $[28]$.

The media dependency theory supports the influence that the U.S. Civil Rights movement had on the struggle across the Atlantic Ocean. The world will never know what would have happened if the civil rights movement in the U.S. had not been broadcast into the homes of common people hungry for information and eager for a model of effective means to counteract injustice.

Marshall McLuhan reminds media researchers that television, as a cool medium, is distinct from the warmer media of radio and print. Television images require participation by the audience to follow a sequence of events. He says, "Images are multisensory, and the interpretation is endlessly open" adding, television strengthens "indepth empathy and participation" [29]. McLuhan explains, "Television encouraged a shift from the detachment of print media to the constant involvement and engagement that television stimulated" [29]. He categorizes television as a unifying medium that "reverses the process of fragmentation and specialization that the print media fosters. It bolsters a seamless web of experience and engenders a global village..."[29].

Media dependency theory, supported by McLuhan's hot and cold media ideas and the uses and gratification model, attempts to explain the changes and change agents in modern societies and places communication technology in the forefront of these transformations.

Alan Nadel [30], Television in Black-and-White America: Race and National Identity, says that the increased visibility of civil rights issues "... owed much to the age of television, as there can be no doubt that national reportage turned segregation from a regional issue to a national and international event" (117). He says the dramatic images "... helped explain how media coverage affected the attitudes toward civil rights and, equally, why prime-time television drama could be effective in rereading these events, turning the specific visual dramas on newscasts into aberrations in a larger historical landscape" (126). Media dependency theory underscores how these images broadcast across the globe influenced the "larger historical landscape" of Northern Ireland. The two movements played out in vastly different ways and Northern Ireland soon embarked on a journey involving complex and serious manifestations of "The Troubles [31]."

Historians, scholars, critics, and eye witnesses run the gamut from those who posit a close parallel between the U.S. and Northern Ireland movements and those who insist that little or no similarities exist. This ambiguity is highlighted by Bob Purdie in Politics in the Streets, when he says, "The adoption of street marches, sit-downs, passive resistance and songs like 'We shall not be moved' and 'We shall overcome' are evidence that the civil rights movement in Northern Ireland saw a close parallel between its activities and the struggle of Blacks in the Deep South. However, on closer examination the parallel proves illusory... (156). Purdie does give credit to the media for its role as information disseminator and provider, he says, "... although the black civil rights movement in the US had been an inspiration, strictly speaking it was not a model. There is no evidence that any of the founders or leaders of the Northern Ireland civil rights movement... undertook a thorough study of that [U.S.] movement. Their information came from the media"(3) [32].

There is no intent here to liken the two movements, but rather put forth the media dependency argument that U.S. media images provided a mass audience in Northern Ireland with information and models for action that led to a renewed spirit in their fight for civil rights in the 1960s.

A Northern Ireland interviewee said, "Looking back to 1969 and the marchers I saw demonstrating in the U.S, I remember feeling a sense of hope. "And whether TV images played a role in the search for new and effective ways to make the silent voices heard, the respondent said, "We had a TV set; all my schoolmates had a TV ... and we watched it as much as mother permitted."

\section{References}

1. Niall OD (1997) From Civil Rights to Armalites: Derry and the Birth of the Irish Troubles. Ireland: Cork University Press.

2. Wasko J (2005) A Companion to Television. Malden, MA: Blackwell Publishing.

3. Ball-Rokeach, Sandra J, DeFleur ML (1976) A Dependency Model of Mass Media Effects. Communication Research 3: 3-21.

4. Conflict Archive on the Internet. CAIN Web Service.

5. Loveless M (2008) Media Dependency: Mass Media as Sources of Information in the Democratizing Countries of Central and Eastern Europe. Democratization 15: 162-183.

6. Kellner D (1981) Network Television and American Society. Theory and Society 10: 31-62.

7. Boyd, Herb (2004) We Shall Overcome. Naperville, IL: Sourcebooks.

8. Garrow, David J (2006) How the Press Reported on Racism, and How It Didn't." Book Review of The Race Beat. The New York Times.

9. Clayborne C (2003) Reporting Civil Rights Part Two, American Journalism 1963-1973. New York: The Library of America.

10. McNair B (1994) News and Journalism in the UK. New York: Routledge.

11. Clayborne C (2003) Reporting Civil Rights Part One, American Journalism 1941-1963. New York: The Library of America.

12. Roberts G, Klibanoff H (2006) The Race Beat: The Press, the Civil Rights Struggle, and the Awakening of a Nation. New York: Knopf.

13. Garrow, David J (2009) Personal Interview.

14. Garrow, David J (1978) Protest at Selma: Martin Luther King, Jr., and the Voting Rights Act of 1965. New Haven: Yale University Press.

15. Fairclough A (2001) To Redeem the Soul of Americas: The Southern Christian Leadership Conference \& Martin Luther King, Jr. University of Georgia Press.

16. Purdie (1990) Politics in the Streets: the origins of the civil rights movement in Northern Ireland. Belfast: The Blackstaff Press.

17. Prince S (2007) Northern Ireland's 68: Civil Rights, Global Revolt and the Origins of the Troubles. Dublin: Irish Academic Press.

18. Farrell M (1976) Northern Ireland: The Orange State. London: Pluto Press.

19. Devlin-McAliskey (2010) Bernadette. Personal Interview.

20. McKenna F (2010) "We Shall Overcome"... The History of the Struggle for Civil Rights in Northern Ireland 1968 - 1978 by NICRA." Conflict Archive on the Internet.

21. Ball-Rokeach, Sandra J (1998) A Theory of Media Power and a Theory of Media Use: Different Stories, Questions, and Ways of Thinking. Mass Communication \& Society, 1: 5-40.

22. Morrison D (2010) Personal Interview.

23. English R (2004) Armed Struggle: The History of the IRA. Oxford: Oxford University Press. 
Citation: Stuart B (2014) From Selma, Alabama, to Derry, Northern Ireland: Media Images and their Influence on Civil Rights Demonstrations. J Mass Communicat Journalism 4: 200. doi:10.4172/2165-7192.1000200

Page 8 of 8

24. English R (2008) Irish Freedom, the History of Nationalism in Ireland. London: Pan Books.

25. Roberts A, Timothy GA (2009) Civil Resistance and Power Politics: The Experience of Non-violent Action from Gandhi to the Present. Oxford: Oxford University Press.

26. English R (2009) Personal Interview.

27. Fionnbarra OD (1994) Ulster's White Negroes. San Francisco: AK Press.

28. Dooley B (1998) Black and Green: The Fight for Civil Rights in Northern Ireland \& Black America. London: Pluto Press.
29. Fishman, Donald A (2006) Rethinking Marshall McLuhan: Reflections on a Media Theorist. Journal of Broadcasting \& Electronic Media 50: 567-574.

30. Nadel, Alan (2005) Television in Black-and-White America. Lawrence, KS: University Press of Kansas.

31. Coogan, Tim Pat (1996) The Troubles: Ireland's ordeal 1966-1996 and the search for peace. Boulder, Co: Roberts Rhinehart Publishers.

32. Spencer G (2005) The Media and Peace: From Vietnam to the "War on Terror." UK: Palgrave Macmillan. 